Original Research

\title{
Influence of Br24 and Gr24 on the Accumulation and Uptake of Cd and As by Rice Seedlings Grown in Nutrient Solution
}

\author{
Bo Xu' ${ }^{1}$, Jinyong Yu${ }^{1}$, Yingsheng Zhong ${ }^{1}$, Yangyang Guo ${ }^{1}$, Jing Ding²*, \\ Yanhui Chen ${ }^{1 * *}$, Guo Wang ${ }^{1}$ \\ ${ }^{1}$ Fujian Provincial Key Laboratory of Soil Environmental Health and Regulation, College of Resources \\ and Environmental Sciences, Fujian Agriculture and Forestry University, Fuzhou, Fujian, China \\ ${ }^{2}$ State Key Laboratory of Urban and Regional Ecology, Research Center for Eco-Environmental Sciences, \\ Chinese Academy of Sciences, Beijing, China
}

Received: 13 July 2018

Accepted: 10 September 2018

\begin{abstract}
Plant hormones are trace organic molecules that play important roles in plant growth, development and stress resistance. 24-epibrassinolide (Br24) and strigolactones (Gr24) were reported to alleviate the toxicity of heavy metals and restrict their translocation into plants. In this study, the effects of $\mathrm{Br} 24$ and Gr24 with or without iron plaque (IP) induction on the uptake and accumulation of cadmium (Cd) and arsenic (As) were examined in rice seedlings exposed to 6-day treatments of $2 \mathrm{mg} \mathrm{L}^{-1} \mathrm{Cd}$ or $5 \mathrm{mg} \mathrm{L}^{-1}$ As in nutrient solution. The results showed that the growth of rice seedlings was decreased by $\mathrm{Cd}$ or As treatment, but $\mathrm{Br} 24$ or Gr24 with or without IP alleviated this adverse effect. Br24 or Gr24 can improve root length, average diameter, surface area, and volume, and tip the number of roots of rice plants with or without IP. Cadmium contents in rice shoots were significantly reduced by Br24 with IP or Gr24, but Cd accumulation and translocation from root to shoot were not decreased. The interaction of $\mathrm{Br} 24$ or Gr24 and IP dramatically increased As contents in rice root, and reduced As translocation from root to shoot. Br24 or Gr24 with IP induction significantly increased Fe content, but decreased the contents of mineral elements $(\mathrm{Mn}, \mathrm{Cu}$ and $\mathrm{Zn}$ ) in rice plants. Our results suggested that the exogenous application of $\mathrm{Br} 24$ or Gr24 could be advantageous against the toxicity of $\mathrm{Cd}$ or As, and a potential way to effectively inhibit Cd or As uptake by rice plants.
\end{abstract}

Keywords: 24-epibrassinolide, strigolactones, iron plaque, heavy metals, rice seedlings

*e-mail: 569222112@qq.com

**e-mail: 382072058@qq.com 


\section{Introduction}

Heavy metal pollution in the environment has been widely concerning $[1,2]$. The pollution of $\mathrm{Cd}$ and As has attracted much attention due to its widespread nature and harmfulness [3-6]. $\mathrm{Cd}$ and $\mathrm{As}$ are not essential elements for plant growth and will have negative effects on the growth and yield of crops when they exceed a certain concentration in the environment, which poses a potential threat to human health through the transmission and accumulation of the food chain [7-10]. Reports have shown that the contents of $\mathrm{Cd}$ and $\mathrm{As}$ in rice on the market exceeded the required standards, resulting in their accumulation in the human body [11, 12]. Long-term consumption of rice with high levels of $\mathrm{Cd}$ or As may induce various diseases like Itai-itai disease, bladder cancer, lung cancer, skin cancer, etc. [13, 14].

Rice is one of the most widely grown crops in the world and a staple for about 3 billion people [15]. Over the past several decades, a large amount of arable land has been polluted by heavy metals from frequent industrial activities [16, 17]. Recent studies have shown that plant hormones can affect the uptake and accumulation of heavy metals in plants [18]. Brassinolide $(\mathrm{Br})$ as a plant hormone was discovered in the 1970s and plays an important role in the regulation of plant growth and development [19, 20]. In addition, several studies have found that $\mathrm{Br}$ can decrease the translocation of heavy metals $(\mathrm{Cu}, \mathrm{Cr}$, $\mathrm{Zn}, \mathrm{Pb}$, and $\mathrm{Cd}$ ) into plants and alleviate their toxicity [18, 21-24]. Nevertheless, limited information can be obtained on whether $\mathrm{Br}$ can decrease the uptake of heavy metals by rice plants. Strigolactone as a plant hormone found in the 1970s can stimulate the germination of parasitic plant seeds, promote mycelial growth of arbuscular mycorrhizal fungi, directly or indirectly inhibit germination of plant lateral bud and coexist with host plants, etc. $[25,26]$. Recent studies have uncovered the fact that synthetic strigolactones (Gr24) can effectively reduce the translocation of Cd to switchgrass [27]. However, it is not clear whether Gr24 will also play a positive regulatory role in response to heavy metal stress in rice plants.

At present, there have been many reports on the effect of iron plaque (IP) on retarding accumulation and uptake of heavy metals by wetland plants. The IP is an iron oxide formed by the oxidation of $\mathrm{Fe}^{2+}$ around the rhizosphere of wetland plants by the oxygen or oxidizing substances secreted from the roots [28]. Iron plaque can adsorb $\mathrm{Cd}$ and $\mathrm{As}$ on root surface of rice plant and decrease their uptake by rice plants to some extent [29, 30]. But whether the interaction between plant hormones and IP can decrease the uptake and accumulation of $\mathrm{Cd}$ or As in rice plants still needs further verification. Therefore, the main aims of this study were to explore two questions on plant hormones application and IP induction to investigate the distribution of $\mathrm{Cd}$ or $\mathrm{As}$ in rice seedlings: (1) Could exogenous $\mathrm{Br} 24$ or Gr24 application effectively reduce $\mathrm{Cd}$ or As uptake by rice plants with or without IP? (2) What are the possible mechanisms for the observed effects? To explain these questions, a hydroponic experiment was designed to test the uptake and translocation of $\mathrm{Cd}$ or As by rice seedlings by soaking seeds in $\mathrm{Br} 24$ solution or adding Gr24 into nutrient solution.

\section{Materials and Methods}

\section{Rice Growth and Experiment Treatment}

Rice seeds (Yongyou1540 purchased in Shufang Town, Nanping City, Fujian Province) were soaked in $30 \% \mathrm{H}_{2} \mathrm{O}_{2}$ for 15 minutes and rinsed thoroughly with deionized water. Half of the seeds were soaked in deionized water and the other half in a $0.1 \mathrm{nM}$ Br24 solution. After $24 \mathrm{~h}$, the rice seeds were evenly spread in the quartz sand for germination. After 16 days, the rice seedlings were transferred to a $20 \times 200 \mathrm{~mm}$ glass tube wrapped in aluminum foil containing 1/4-strength Hoagland solution, which was changed every 3 days and the $\mathrm{pH}$ was adjusted to 5.5. After 10 days, the rice seedlings were transferred to deionized water for 12 hours, and then IP was induced: (1) rice seedlings without IP induction: grown in 1/4-strength Hoagland solution (-P) for 3 days to avoid precipitation of $\mathrm{P}$ and $\mathrm{Fe}$; (2) rice seedlings with IP induction: grown in 1/4-strength Hoagland solution including 30 or $70 \mathrm{mg} \mathrm{L}^{-1} \mathrm{Fe}^{2+}$ (-P, -Fe(II)-EDTA) for 3 days. Iron plaque induced by 30 or $70 \mathrm{mg} \mathrm{L}^{-1} \mathrm{Fe}^{2+}$ were called IP30 and IP70, respectively. After that, these rice seedlings were grown in 1/4-strength Hoagland solution for 5 days for recovery growth. Then, rice seedlings were grown in 1/4-strength Hoagland solution, including $5 \mathrm{mg} \mathrm{L}^{-1} \mathrm{As}\left(\mathrm{Na}_{3} \mathrm{AsO}_{4} \cdot 12 \mathrm{H}_{2} \mathrm{O}\right)$ or $2 \mathrm{mg} \mathrm{L}{ }^{-1} \mathrm{Cd}\left(\mathrm{Cd}\left(\mathrm{NO}_{3}\right)_{2} \cdot 4 \mathrm{H}_{2} \mathrm{O}\right)$ with or without $1 \mu \mathrm{M}$ Gr24 addition for 6 days. The total combinations of Br24 or Gr24 with or without IP gave 15 treatments, each in triplicate (Table 1). The experiment was carried

Table 1. Experiment treatment.

\begin{tabular}{|c|c|c|c|c|}
\hline No Br24 or Gr24 treatment & \multicolumn{2}{|c|}{ Br24 treatment } & \multicolumn{2}{c|}{ Gr24 treatment } \\
\hline Control & Br24+Cd & Br24+As & Gr24+Cd & Gr24+As \\
\hline Cd & Br24+IP30+Cd & Br24+IP30+As & Gr24+IP30+Cd & Gr24+IP30+As \\
\hline As & Br24+IP70+Cd & Br24+IP70+As & Gr24+IP70+Cd & Gr24+IP70+As \\
\hline
\end{tabular}


out in a greenhouse at $25-35^{\circ} \mathrm{C}$ with light exposure of $12-14 \mathrm{~h} \mathrm{~d}^{-1}$

\section{Tissue Elements Analysis}

At harvest, the rice seedlings were divided into two parts of root and shoot, and washed with deionized water. The fresh roots were scanned in a root scanner, and then placed in a $70^{\circ} \mathrm{C}$ oven with shoots for $72 \mathrm{~h}$. Afterward, oven-dried root and shoot samples were ground and soaked in a microwave digestion tube with $8 \mathrm{~mL} \mathrm{HNO}_{3}$ overnight. Then $1 \mathrm{~mL} \mathrm{H}_{2} \mathrm{O}_{2}$ (30\%) was added into a microwave digestion tube and the digestion process was carried out for 4 hours at $95^{\circ} \mathrm{C}$. The digestion solution was transferred to a volumetric flask and filtered using a $0.45 \mu \mathrm{m}$ filter. Reagent blank and standard reference material (bush twigs and leaves, GBW07603, Chinese National Certified Reference Material) are used for quality control and analysis of the digestion procedure. Concentrations of $\mathrm{Cd}, \mathrm{As}, \mathrm{Fe}, \mathrm{Mn}$, $\mathrm{Cu}$ and $\mathrm{Zn}$ in roots and shoots were determined using induced couple plasma mass spectrometry (ICP-MS, NexION 300X; Perkin Elmer, NY).

\section{Statistical Analysis}

One-way ANOVA (analysis of variance) was carried out using SPSS software (19.0, SPSS, Inc., Chicago, IL, USA). The effects of Br24 and Gr24 with or without IP were tested on rice seedling biomass, root parameters and the concentrations of $\mathrm{Cd}, \mathrm{As}, \mathrm{Fe}, \mathrm{Mn}, \mathrm{Cu}$ and $\mathrm{Zn}$ in rice plants. Data presented are means $\pm \mathrm{SE}(\mathrm{n}=3)$, and were analyzed using least significant difference (LSD) at the $5 \%$ level.

\section{Results and Discussion}

To examine whether $\mathrm{Cd}$ or As affected the growth of rice seedlings under $\mathrm{Br} 24$ or Gr24 with or without IP, we analyzed plant biomass and root parameters, including length, surface area, volume, diameter and tips of root (Figs 1 and 2). Biomass of rice shoot was decreased by $\mathrm{Cd}$, but increased by Br24 or Gr24 with or without IP (Fig. 1). With respect to the control, Br24 or Gr24 also significantly increased root biomass of rice seedlings exposed to Cd stress (Fig. 1). Arsenic exposure did not
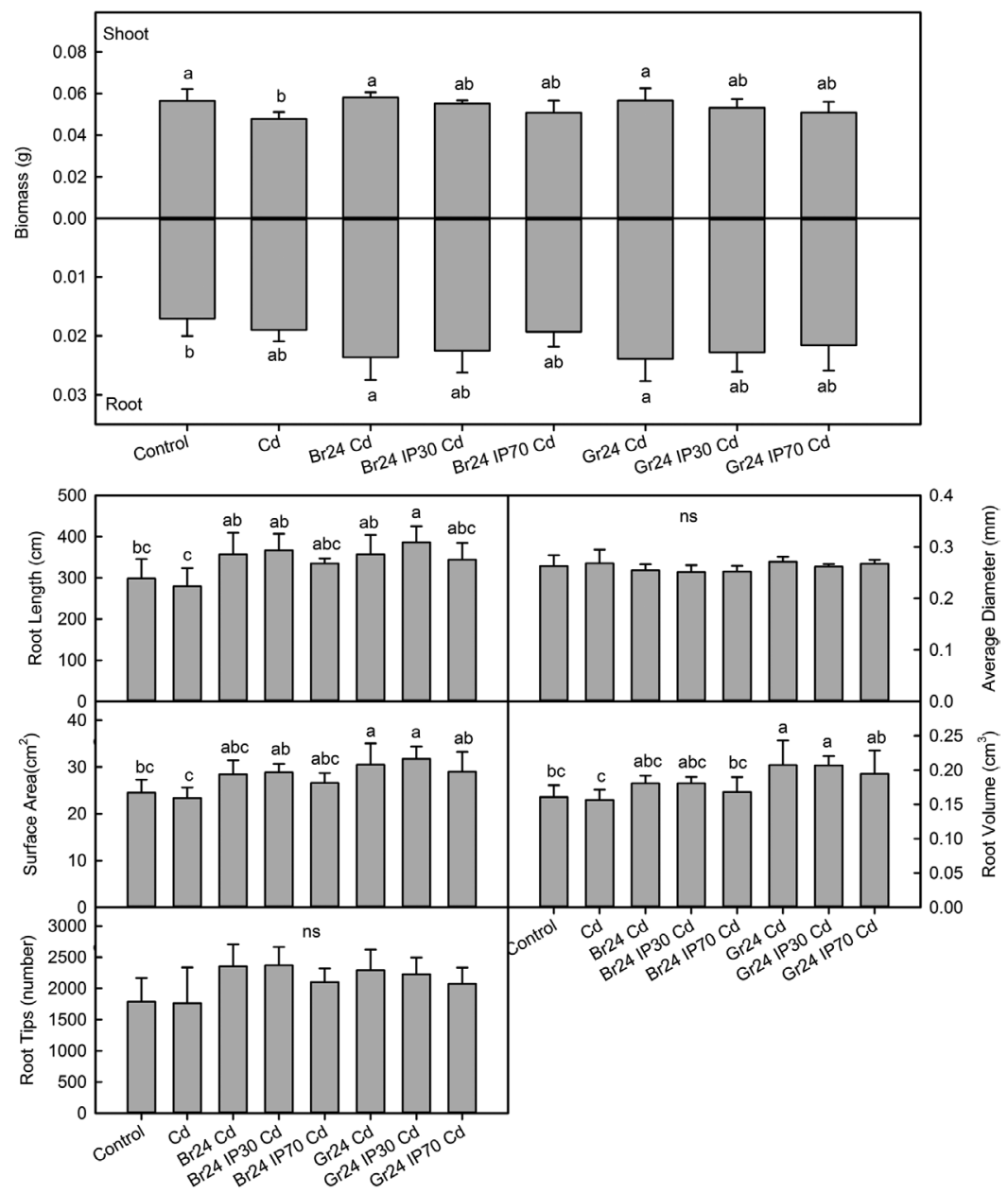

Fig. 1. Effects of Br24 (0.1 nM) or Gr24 $(1 \mu \mathrm{M})$ with or without iron plaque (30 and $70 \mathrm{mg} \mathrm{L}^{-1} \mathrm{Fe}$ : IP30 and IP70) on biomass of rice seedlings and root parameters exposed to $\mathrm{Cd}\left(2 \mathrm{mg} \mathrm{L}^{-1}\right)$. Different letters indicate significant differences at $p<0.05$ using least significant difference (LSD) (means \pm SE, $n=3$ ). 

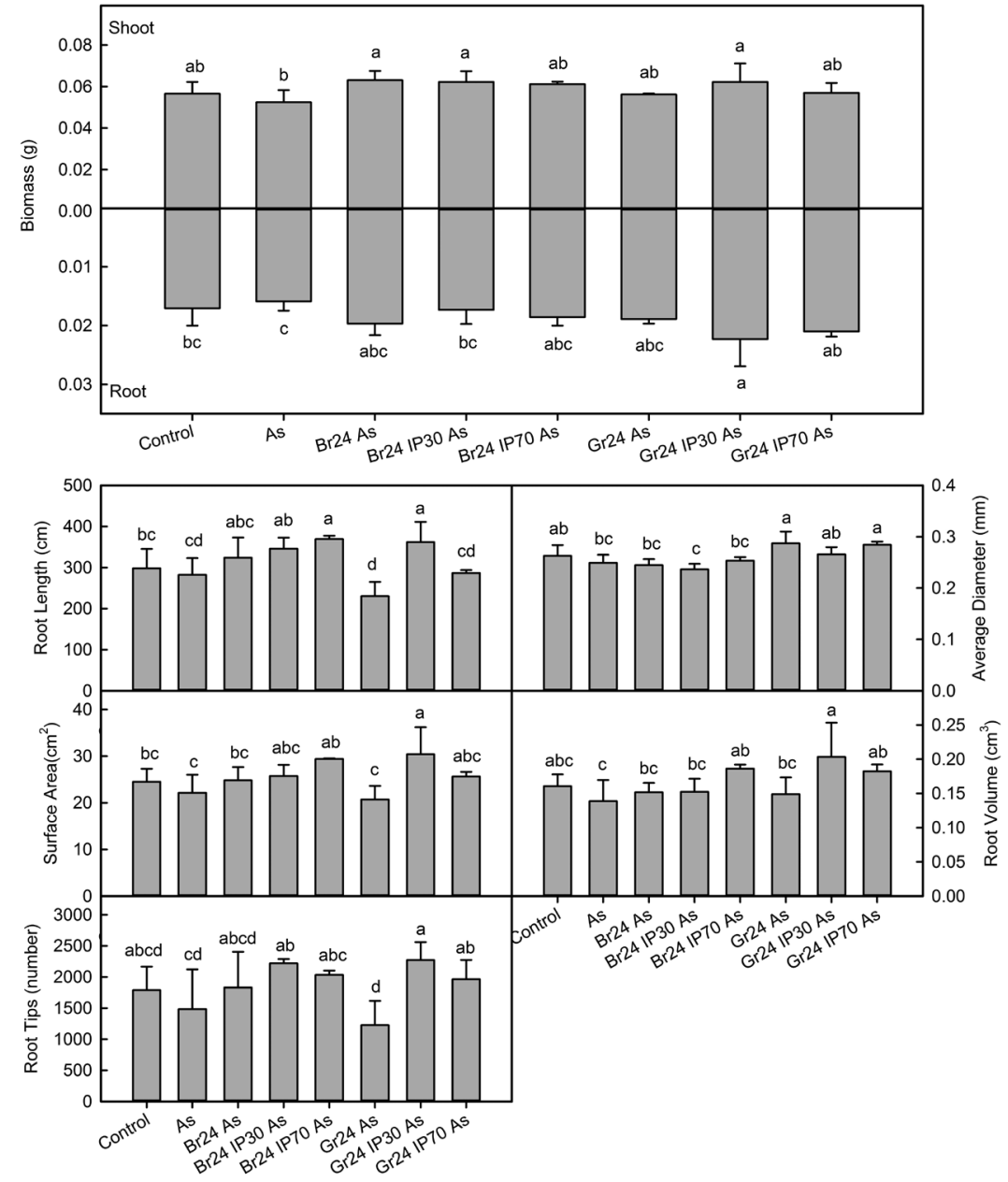

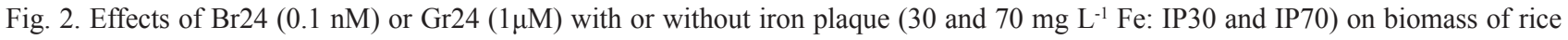
seedlings and root parameters exposed to As $\left(5 \mathrm{mg} \mathrm{L}^{-1}\right)$. Different letters indicate significant differences at $p<0.05$ using least significant difference (LSD) (means \pm SE, $n=3$ ).

affect biomass of rice seedlings (Fig. 2). In comparison with As treatment, Gr24 with IP30 promoted biomass of shoot and root, and Br24 with or without IP30 increased shoot biomass (Fig. 2). Cadmium and As are not essential elements for higher plant growth, and excessive $\mathrm{Cd}$ or As exposure has been reported to cause adverse effects on growth and yield of rice plant [31, 32]. Our previous work indicated that $0.02 \mu \mathrm{M} \mathrm{Br} 24$ alleviated $\mathrm{Cd}$ and As negative effects on biomass of rice with IP20 [33]. A recent study showed that Gr24 can alleviate Cd toxicity to switchgrass seedlings [27]. These results were in line with the present study, revealing that 0.1 $\mu \mathrm{M}$ Br24 or $1 \mu \mathrm{M} \mathrm{Gr} 24$ promoted rice growth under As or Cd treatment (Figs 1 and 2).

Compared with the control group, Cd treatment did not affect the length, surface area, diameter, volume and tip numbers of rice roots (Fig. 1). In comparison with Cd treatment, Br24 or Gr24 markedly increased the root length with or without IP30 (Fig. 1). Gr24 with or without IP30 or IP70 significantly increased root surface area and volume (Fig. 1). In comparison with the control group, the root parameters were also not affected by As treatment (Fig. 2). Br24 with IP30 or IP70 and
Gr24 with IP30 significantly stimulated root length in comparison with As treatment (Fig. 2). Root diameter, surface area, volume and tips were increased by Gr24 with or without IP30 or IP70, Br24 with IP70 and Gr24 with IP30, Br24 with IP70 and Gr24 with IP30 or IP70, and Br24 with IP30 and Gr24 with IP30 or IP70, respectively (Fig. 2). These results indicated that $\mathrm{Br} 24$ or Gr24 with or without IP neutralized the decrease in root parameters of rice seedlings under Cd or As stress, which was supported by Kapoor et al. [34] showing that the decline in root length of Raphanus sativus seedling under $\mathrm{Cd}$ stress was alleviated by $\mathrm{Br} 24$ (0.1, 0.01 and $0.001 \mu \mathrm{M}$ ), and Tai et al. [27] reporting that $1 \mu \mathrm{M} \mathrm{Gr} 24$ increased root length, surface area, volume and tips of switchgrass seedlings under $\mathrm{Cd}$ stress. $\mathrm{Br} 24$ also can relieve the toxic effect of $\mathrm{Ni}, \mathrm{Hg}$ and $\mathrm{Cr}$ on the growth of Raphanus sativus L., chickpea seedlings and Oryza sativa L. by protecting photosynthesis and improving antioxidant enzyme activity [18, 35, 36].

Cadmium content in shoots was significantly decreased by Br24 with IP30 and Gr24 (Fig. 3). Root Cd content was obviously decreased by Gr24 with or without IP30 or IP70. However, Br24 or Gr24 did not 
decrease $\mathrm{Cd}$ translocation to rice shoot (Fig. 3). The total amount of $\mathrm{Cd}$ ranged from $1.63-1.90 \mu \mathrm{g}$ in shoots and from 10.24-13.40 $\mu \mathrm{g}$ in roots (Fig. 3). Root Cd content was increased by $\mathrm{Br} 24$, and decreased by Gr24 with IP70. Br24 or Gr24 with or without IP did not markedly affect the amount of $\mathrm{Cd}$ in shoots. The highest proportion $(85 \%-88 \%)$ of $\mathrm{Cd}$ was concentrated in rice roots (Fig. 3).

Our results were partly consistent with those reported by RADY et al. [23] and Tai et al. [27], who observed Br24 and Gr24 significantly decreased $\mathrm{Cd}$ contents in Phaseolus vulgaris L. and switchgrass seedlings. Iron plaque can inhibit $\mathrm{Cd}$ uptake by rice seedlings under low-dose $\mathrm{Cd}$ exposure $\left(0.1 \mathrm{mg} \mathrm{L}^{-1}\right)$, but not under $1.0 \mathrm{mg} \mathrm{L}^{-1}$ [37]. However, in the present study the results showed that IP30 obviously decreased Cd uptake by rice seedlings exposed to $5 \mathrm{mg} \mathrm{L}^{-1} \mathrm{Cd}$ in the presence of $\mathrm{Br} 24$ or $\mathrm{Gr} 24$. This indicates that a positive role of $\mathrm{Br} 24$ with IP occurred in decreasing Cd uptake by rice plants. Our previous study also demonstrated that $\mathrm{Cd}$ in rice plants was markedly decreased by the interaction of $\mathrm{Br} 24$ and IP [33]. It was speculated that $\mathrm{Br} 24$ and $\mathrm{Fe}$ could play a certain defensive role in coping with $\mathrm{Cd}$ stress. Br24 can decrease shoot Fe content and increase root Fe content of rice seedlings with Fe-sufficient or Fedeficient medium [38]. Our previous study also showed that $\mathrm{Br} 24$ increased $\mathrm{Fe}$ content in rice roots, but not in shoots without $\mathrm{Cd}$ stress, and did not affect Fe content in rice plants with $\mathrm{Cd}$ treatment [33]. This contrary result can be attributed to different rice varieties. In this study, our results showed no significant effect of Br24 on $\mathrm{Fe}$ content in rice plants in the presence of $\mathrm{Cd}$ or As treatment. The different application method of $\mathrm{Br} 24$ may be one of the reasons for these dissimilar results. Soaking seeds or foliar spraying or foliar spraying at different plant growth stages all determined the Br's effects on $\mathrm{Cd}$ uptake by plants [22, 39]. In addition, nitric oxide (NO) was reported to be involved in the reduction of $\mathrm{Cd}$ in plants [40], but did not increase $\mathrm{Fe}$ content in plants. It can be seen that reducing $\mathrm{Cd}$ uptake by plants is not only due to the increasing Fe supply, but a very complicated process, although Liu et al. [29] reported that increasing Fe supply decreased Cd content in rice plants. This was in line with our results showing that Gr24 decreased Cd uptake by rice plants in the absence of IP (Fig. 3). At present, there are few reports on the effect of Gr24 on the translocation and uptake of heavy metals in plants. Only Tai et al. [27] showed that
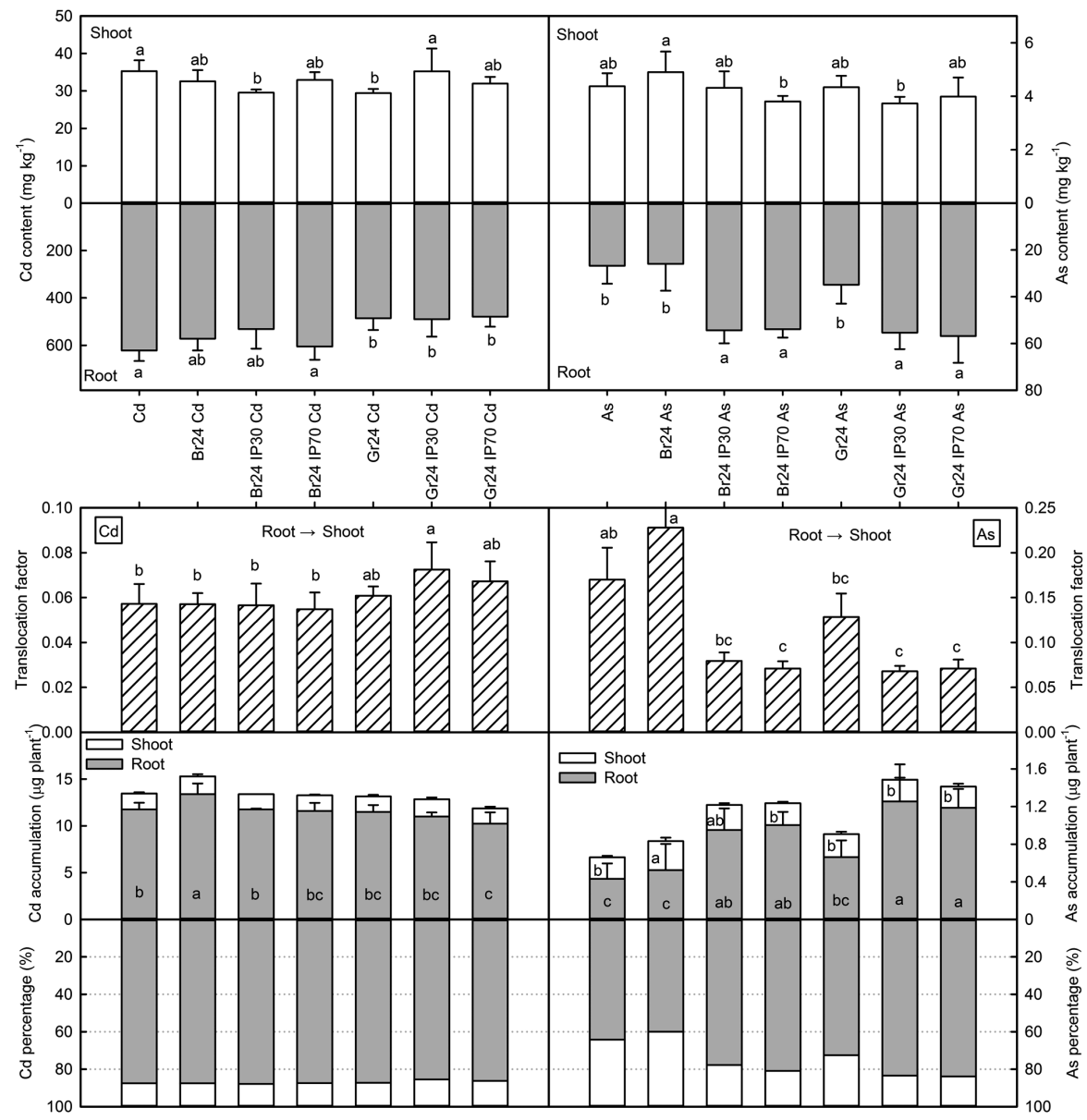

Fig. 3. Effects of $\operatorname{Br} 24(0.1 \mathrm{nM})$ or $\mathrm{Gr} 24(1 \mu \mathrm{M})$ with or without iron plaque (30 and $70 \mathrm{mg} \mathrm{L}^{-1} \mathrm{Fe}$ : IP30 and IP70) on contents, translocation factor and accumulation of $\mathrm{Cd}$ or As in shoots and roots of rice seedlings exposed to $\mathrm{Cd}\left(2 \mathrm{mg} \mathrm{L}^{-1}\right)$ or As $\left(5 \mathrm{mg} \mathrm{L}^{-1}\right)$ stress. Different letters indicate significant differences at $p<0.05$ using least significant difference (LSD) (means $\pm \mathrm{SE}, n=3$ ). 


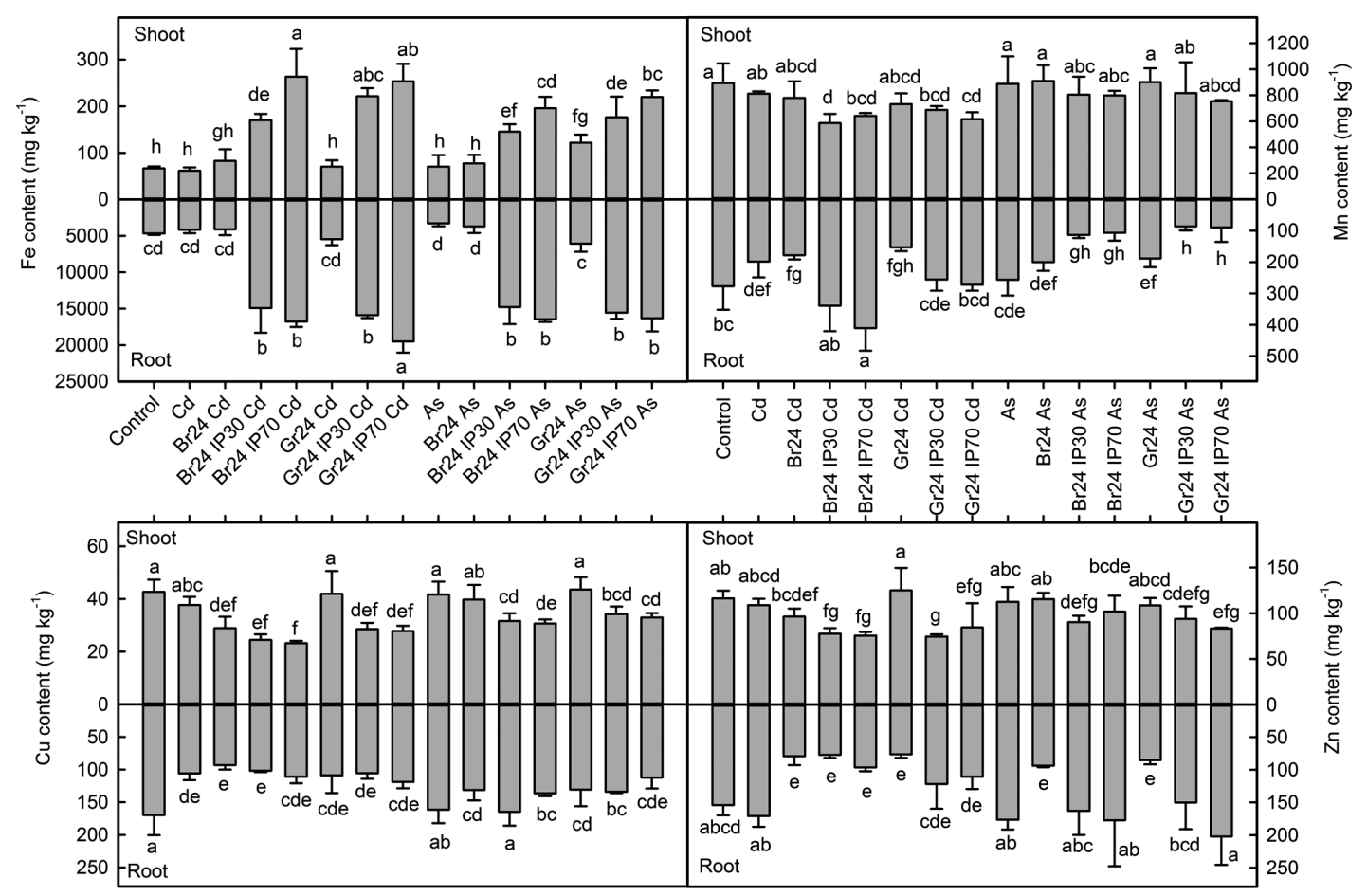

Fig. 4. Effects of Br24 (0.1 nM) or Gr24 $(1 \mu \mathrm{M})$ with or without iron plaque (30 and $70 \mathrm{mg} \mathrm{L}^{-1} \mathrm{Fe}$ : IP30 and IP70) on contents of Fe, Mn, $\mathrm{Cu}$ and $\mathrm{Zn}$ in shoots and roots of rice seedlings exposed to $\mathrm{Cd}\left(2 \mathrm{mg} \mathrm{L}^{-1}\right)$ or As $\left(5 \mathrm{mg} \mathrm{L}^{-1}\right)$ stress. Different letters indicate significant differences at $p<0.05$ using least significant difference (LSD) (means \pm SE, $n=3$ ).

the reason for Gr24 reducing Cd uptake by switchgrass seedling might be attributed to the improvement of some essential elements ( $\mathrm{Fe}, \mathrm{Mn}, \mathrm{Cu}$ and $\mathrm{Zn}$ ). However, no significant increase in these elements in rice plants was found in our results (Fig. 4). It is noticed that the contents of $\mathrm{Mn}, \mathrm{Cu}$ and $\mathrm{Zn}$ in shoots and roots of rice plant were reduced by IP induction (Fig. 4). Recent studies reported that $\mathrm{NO}$ and $\mathrm{Gr} 24$ interacted in plants inducing stomatal closure [41] and root elongation [42], and Gr24 can stimulate a significant increase in NO contents. Therefore, it can be inferred that Gr24 possibly regulated the response of plants to $\mathrm{Cd}$ stress by stimulating NO-enhancing antioxidant enzyme activity.

Br24 or Gr24 did not affect As content in shoots of rice seedlings with or without IP, but markedly increased As content of rice roots with IP30 or IP70 (Fig. 3). Br24 or Gr24 significantly decreased As translocation to rice shoots with IP30 or IP70 (Fig. 3). The total amount of As in shoots of rice ranged from $0.23-0.31 \mu \mathrm{g}$ and from 0.43-1.25 $\mu \mathrm{g}$ in roots (Fig. 3). Arsenic content in rice shoots was increased by $\mathrm{Br} 24$, and root As content was enhanced by $\mathrm{Br} 24$ or Gr24 with IP. The proportion of As was $64 \%$ in roots and $36 \%$ in shoots, respectively. Br24 or Gr24 with IP decreased the proportion $(16-22 \%)$ of As in rice shoots. Our previous study showed that As content in rice shoots was decreased by $0.02 \mu \mathrm{M} \mathrm{Br} 24$, but not by $0.2 \mu \mathrm{M} \mathrm{Br} 24$; and the interaction of IP induction and 0.02 or $0.2 \mu \mathrm{M}$ Br24 can increase shoot As content [33]. This indicated that As uptake by rice plants was determined by different
Br24 concentrations. Our results showed that IP induction also did not affect As uptake by rice shoots, but increased As uptake and accumulation in rice roots (Fig. 3), which was supported by Liu et al. [43, 44], who found a significant positive relationship between $\mathrm{Fe}$ and As concentrations in shoots or plaque. Singh et al. [45] reported that NO can decrease As content in rice plants, probably by down-regulating the expression of OsLsil and OsLsi2 and enhancing the Fe accumulation. In this study, although Fe content was increased by Gr24 under As stress, As content in rice plants was not affected. The reason for this dissimilar result may be due to the different NO supply. Farnese et al. [46] found that $0.1 \mathrm{mg} \mathrm{L}^{-1} \mathrm{NO}$ did not affect As content in Pistia stratiotes. In addition, As concentrations in environmental media also affected NO's effect on As contents in plants. For example, Namdjoyan et al. [47] showed that NO can significantly decrease As content in shoots of watercress plants under 50, 75 and 100 $\mu \mathrm{M}$ As treatments, but not under $25 \mu \mathrm{M}$ As. However, the reasons why Gr24 or Br24 with or without IP can affect or reduce As or Cd translocation and uptake in rice plants still needs to be studied and discussed in the future.

\section{Conclusions}

In this study, plant hormone-Br24 or Gr24 with or without IP induction was applied to a rice-nutrient 
solution system to investigate its potential effect on $\mathrm{Cd}$ or As uptake by rice seedlings. The results showed that $\mathrm{Br} 24$ or Gr24 can improve the growth of rice seedlings with or without IP. Br24 with IP or Gr24 significantly decreased $\mathrm{Cd}$ content in rice shoots, but $\mathrm{Cd}$ accumulation and translocation from root to shoot were not reduced. Although arsenic content in rice plants was not decreased, As translocation from root to shoot was markedly reduced by the interaction of Br24 or Gr24 and IP. Although we have discussed the uptake and accumulation of $\mathrm{Cd}$ and $\mathrm{As}$ in rice seedlings and explained the reasons for that, many of them cannot be confirmed due to the lack of research in this field at present, especially for Gr24's effect. Subsequent studies are still needed to further verify the effect of $\mathrm{Br} 24$ or $\mathrm{Gr} 24$ on the accumulation of $\mathrm{Cd}$ or As in rice grains and explore the possible molecular mechanism.

\section{Acknowledgements}

This study was financed by the National Science Foundation of China (31500319).

\section{Conflict of Interest}

The authors declare no conflict of interest.

\section{References}

1. MEN C., LIU R.M., XU F., WANG Q.R., GUO L.J., SHEN Z.Y. Pollution characteristics, risk assessment, and source apportionment of heavy metals in road dust in Beijing, China. Science of the Total Environment, 612, 138, 2018.

2. GUO F.H., ZHONG Z.P. Pollution emission and heavy metal speciation from co-combustion of sedum plumbizincicola and sludge in fluidized bed. Journal of Cleaner Production, 179, 317, 2018.

3. PINTER I.F., SALOMON M.V., GIL R., MASTRANTONIO L., BOTTINI R., PICCOLI P. Arsenic and trace elements in soil, water, grapevine and onion in Jachal, Argentina. Science of the Total Environment, 615, 1485, 2018.

4. CUI J.L., ZHAO Y.P., LI J.S., BEIYUAN J.Z., TSANG D.C.W., POON C.S., CHAN T.S., WANG W.X., LI X.D. Speciation, mobilization, and bioaccessibility of arsenic in geogenic soil profile from Hong Kong. Environmental Pollution, 232, 375, 2018.

5. LIU C.S., CHANG C.Y., FEI Y.H., LI F.B., WANG Q., ZHAI G.S., LEI J. Cadmium accumulation in edible flowering cabbages in the Pearl River Delta, China: Critical soil factors and enrichment models. Environmental Pollution, 233, 880, 2018.

6. YANG Y.J., CHEN J.M., HUANG Q.N., TANG S.Q., WANG J.L., HU P.S., SHAO G.S. Can liming reduce cadmium (Cd) accumulation in rice (Oryza sativa) in slightly acidic soils? A contradictory dynamic equilibrium between $\mathrm{Cd}$ uptake capacity of roots and $\mathrm{Cd}$ immobilisation in soils. Chemosphere, 193, 547, 2018.
7. AZIZ R., RAFIQ M.T., LI T.Q., LIU D., HE Z.L., STOFFELLA P.J., SUN K., XIAOE Y. Uptake of cadmium by rice grown on contaminated soils and its bioavailability/ toxicity in human cell lines (Caco-2/HL-7702). Journal of Agricultural and Food Chemistry, 63, 3599, 2015.

8. ZHENG M.Z., LI G., SUN G.X., SHIM H., CAI C. Differential toxicity and accumulation of inorganic and methylated arsenic in rice. Plant and Soil, 365, 227, 2013.

9. SINHA B., BHATTACHARYYA K. Arsenic toxicity in rice with special reference to speciation in Indian grain and its implication on human health. Journal of the Science of Food and Agriculture, 95, 1435, 2015.

10. ZHANG Y.F., LIU P., WANG C.N., WU Y.N. Human health risk assessment of cadmium via dietary intake by children in Jiangsu Province, China. Environmental Geochemistry and Health, 39, 29, 2017.

11. ISLAM S., RAHMAN M.M., DUAN L.C., ISLAM M.R., KUCHEL T., NAIDU R. Variation in arsenic bioavailability in rice genotypes using swine model: An animal study. Science of the Total Environment, 599, 324, 2017.

12. DAI H.W., SONG X.X., HUANG B.F., XIN J.L. Health risks of heavy metals to the general public in Hengyang, China, via consumption of rice. Human and Ecological Risk Assessment, 22, 1636, 2016.

13. AOSHIMA K. Itai-itai disease: Renal tubular osteomalacia induced by environmental exposure to cadmiumhistorical review and perspectives. Soil Science and Plant Nutrition, 62, 319, 2016.

14. OBEROI S., BARCHOWSKY A., WU F. The global burden of disease for skin, lung, and bladder cancer caused by arsenic in Food. Cancer Epidemiology Biomarkers and Prevention, 23, 1187, 2014.

15. CHENG H., WANG M.Y., WONG M.H., YE Z.H. Does radial oxygen loss and iron plaque formation on roots alter $\mathrm{Cd}$ and $\mathrm{Pb}$ uptake and distribution in rice plant tissues? Plant and Soil, 375, 137, 2014.

16. TOTH G., HERMANN T., DA SILVA M.R., MONTANARELLA L. Heavy metals in agricultural soils of the European Union with implications for food safety. Environment International, 88, 299, 2016.

17. CHEN H.Y., TENG Y.G., LU S.J., WANG Y.Y., WANG J.S. Contamination features and health risk of soil heavy metals in China. Science of the Total Environment, 512, 143, 2015.

18. SHARMA P., KUMAR A., BHARDWAJ R. Plant steroidal hormone epibrassinolide regulate - Heavy metal stress tolerance in Oryza sativa L. by modulating antioxidant defense expression. Environmental and Experimental Botany, 122, 1, 2016.

19. MITCHELL J.W., MANDAVA N., WORLEY J.F., PLIMMER J.R., SMITH M.V. Brassins--a new family of plant hormones from rape pollen. Nature, 225, 1065, 1970.

20. GUDESBLAT G.E., RUSSINOVA E. Plants grow on brassinosteroids. Current Opinion in Plant Biology, 14, 530, 2011.

21. BAJGUZ A., HAYAT S. Effects of brassinosteroids on the plant responses to environmental stresses. Plant Physiology and Biochemistry, 47, 1, 2009.

22. KROUTIL M., HEJTMANKOVA A., LACHMAN J. Effect of spring wheat (Triticum aestivum L.) treatment with brassinosteroids on the content of cadmium and lead in plant aerial biomass and grain. Plant Soil and Environment, 56, 43, 2010.

23. RADY M.M. Effect of 24-epibrassinolide on growth, yield, antioxidant system and cadmium content of bean 
(Phaseolus vulgaris L.) plants under salinity and cadmium stress. Scientia Horticulturae, 129, 232, 2011.

24. YUSUF M., KHAN T.A., FARIDUDDIN Q. Interaction of epibrassinolide and selenium ameliorates the excess copper in Brassica juncea through altered proline metabolism and antioxidants. Ecotoxicology and Environmental Safety, 129, 25, 2016.

25. AKIYAMA K., MATSUZAKI K.-I., HAYASHI H. Plant sesquiterpenes induce hyphal branching in arbuscular mycorrhizal fungi. Nature, 435, 824, 2005.

26. GOMEZ-ROLDAN V., FERMAS S., BREWER P.B., PUECH-PAG S V., DUN E.A., PILLOT J.P., LETISSE F., MATUSOVA R., DANOUN S., PORTAIS J.-C., BOUWMEESTER H., B CARD G., BEVERIDGE C.A., RAMEAU C., ROCHANGE S.F. Strigolactone inhibition of shoot branching. Nature, 455, 189, 2008.

27. TAI Z.L., YIN X.Q., FANG Z.G., SHI G.L., LOU L.Q., CAI Q.S. Exogenous GR24 alleviates cadmium toxicity by reducing cadmium uptake in switchgrass (Panicum virgatum) seedlings. International Journal of Environmental Research and Public Health, 14, 2017.

28. KHAN N., SESHADRI B., BOLAN N., SAINT C.P., KIRKHAM M.B., CHOWDHURY S., YAMAGUCHI N., LEE D.Y., LI G., KUNHIKRISHNAN A., QI F., KARUNANITHI R., QIU R., ZHU Y.G., SYU C.H. Root iron plaque on wetland plants as a dynamic pool of nutrients and contaminants. Advances in Agronomy, 138, $1,2016$.

29. LIU H.J., ZHANG J.L., CHRISTIE P., ZHANG F.S. Influence of iron plaque on uptake and accumulation of $\mathrm{Cd}$ by rice (Oryza sativa L.) seedlings grown in soil. Science of the Total Environment, 394, 361, 2008.

30. MEHARG A.A. Arsenic in rice - understanding a new disaster for South-East Asia. Trends in Plant Science, 9, 415, 2004.

31. PANAULLAH G.M., ALAM T., HOSSAIN M.B., LOEPPERT R.H., LAUREN J.G., MEISNER C.A., AHMED Z.U., DUXBURY J.M. Arsenic toxicity to rice (Oryza sativa L.) in Bangladesh. Plant and Soil, 317, 31, 2009.

32. FAROOQ M.A., DETTERBECK A., CLEMENS S., DIETZ K.J. Silicon-induced reversibility of cadmium toxicity in rice. Journal of Experimental Botany, 67, 3573, 2016.

33. XU B., YU J.Y., XIE T., LI Y.L., LIU M.J., GUO J.X., LI H.L., YU Y., ZHENG C.Y., CHEN Y.H., WANG G. Brassinosteroids and iron plaque affect arsenic and cadmium uptake by rice seedlings grown in hydroponic solution. Biologia Plantarum, 62, 362, 2018.

34. KAPOOR D., RATTAN A., GAUTAM V., BHARDWAJ R. Alleviation of cadmium and mercury stress by supplementation of steroid hormone to raphanus sativus seedlings. Proceedings of the National Academy of Sciences, India Section B: Biological Sciences, 86, 661, 2016.

35. SHARMA I., PATI P.K., BHARDWAJ R. Effect of 24-epibrassinolide on oxidative stress markers induced by nickel-ion in Raphanus sativus L. Acta Physiologiae Plantarum, 33, 1723, 2011.
36. AHMAD P., AHANGER M.A., EGAMBERDIEVA D., ALAM P., ALYEMENI M.N., ASHRAF M. Modification of osmolytes and antioxidant enzymes by 24-epibrassinolide in chickpea seedlings under mercury (Hg) toxicity. Journal of Plant Growth Regulation, 37, 309, 2018.

37. LIU H.J., ZHANG J.L., ZHANG F.S. Role of iron plaque in Cd uptake by and translocation within rice (Oryza sativa L.) seedlings grown in solution culture. Environmental and Experimental Botany, 59, 314, 2007.

38. WANG B.L., LI G., ZHANG W.H. Brassinosteroids are involved in $\mathrm{Fe}$ homeostasis in rice (Oryza sativa L.). Journal of Experimental Botany, 66, 2749, 2015.

39. KAUR R., YADAV P., SHARMA A., THUKRAL A.K., KUMAR V., KOHLI S.K., BHARDWAJ R. Castasterone and citric acid treatment restores photosynthetic attributes in Brassica juncea L. under Cd(II) toxicity. Ecotoxicology and Environmental Safety, 145, 466, 2017.

40. HE J.Y., REN Y.F., CHEN X.L., CHEN H. Protective roles of nitric oxide on seed germination and seedling growth of rice (Oryza sativa L.) under cadmium stress. Ecotoxicology and Environmental Safety, 108, 114, 2014.

41. LV S., ZHANG Y.H., LI C., LIU Z.J., YANG N., PAN L.X., WU J.B., WANG J.J., YANG J.W., LV Y.T., ZHANG Y.T., JIANG W.Q., SHE X.P., WANG G.D. Strigolactonetriggered stomatal closure requires hydrogen peroxide synthesis and nitric oxide production in an abscisic acidindependent manner. New Phytologist, 217, 290, 2018.

42. SUN H.W., BI Y., TAO J.Y., HUANG S.J., HOU M.M., XUE R., LIANG Z.H., GU P.Y., YONEYAMA K., XIE X.N., SHEN Q.R., XU G.H., ZHANG Y.L. Strigolactones are required for nitric oxide to induce root elongation in response to nitrogen and phosphate deficiencies in rice. Plant Cell and Environment, 39, 1473, 2016.

43. LIU W.J., ZHU Y.G., SMITH F.A. Effects of iron and manganese plaques on arsenic uptake by rice seedlings (Oryza sativa L.) grown in solution culture supplied with arsenate and arsenite. Plant and Soil, 277, 127, 2005.

44. LIU W.J., ZHU Y.G., SMITH F.A., SMITH S.E. Do iron plaque and genotypes affect arsenate uptake and translocation by rice seedlings (Oryza sativa L.) grown in solution culture? Journal of Experimental Botany, 55, 1707, 2004.

45. SINGH A.P., DIXIT G., KUMAR A., MISHRA S., KUMAR N., DIXIT S., SINGH P.K., DWIVEDI S., TRIVEDI P.K., PANDEY V., DHANKHER O.P., NORTON G.J., CHAKRABARTY D., TRIPATHI R.D. A protective role for nitric oxide and salicylic acid for arsenite phytotoxicity in rice (Oryza sativa L.). Plant Physiology and Biochemistry, 115, 163, 2017.

46. FARNESE F.S., OLIVEIRA J.A., PAIVA E.A.S., MENEZES-SILVA P.E., DA SILVA A.A., CAMPOS F.V., RIBEIRO C. The involvement of nitric oxide in integration of plant physiological and ultrastructural adjustments in response to arsenic. Frontiers in Plant Science, 8, 2017.

47. NAMDJOYAN S., KERMANIAN H. Exogenous nitric oxide (as sodium nitroprusside) ameliorates arsenicinduced oxidative stress in watercress (Nasturtium officinale R. Br.) plants. Scientia Horticulturae, 161, 350, 2013. 